Almeida, C., Morais, C., Miranda, L., Viseu, F., \& Martinho, H. (2002). Student teachers' perceptions of the internet: Motivation, influences, and use. In IEEE - Computer Society, Proceedings International Conference on Computers in Education (ICCE) (5 páginas PDF). Auckland (New Zealand): Massey University. 


\title{
Student Teachers' Perceptions of the Internet: Motivation, Influences, and Use
}

\author{
Conceição Almeida, University of Minho, Portugal, calmeida@iep.uminho.pt \\ Carlos Morais, Bragança Polytechnic Institute, Portugal, cmmm@ipb.pt \\ Luísa Miranda, Bragança Polytechnic Institute, Portugal, Imiranda@ipb.pt \\ Floriano Viseu, University of Minho, Portugal, fviseu@iep.uminho.pt \\ Helena Martinho, University of Minho, Portugal, mhm@iep.uminho.pt
}

\begin{abstract}
The Internet's rapid growth and diffusion, both worldwide and in our country, as well as its importance for teacher education, made us feel the need to reflect on how our student teachers integrate themselves in such quite novel environmental conditions and teaching communities. This paper reports on one specific Portuguese university's student teachers' Internet usage during their teaching practice and what reasons motivated them to do so. It also lonks into student teachers' perceptions about Internet discussion and usage by other teachers in their schools and, in particular, in their own disciplinary groups. The data was collected using a questionnaire which was anonymously answered by 189 of the entire 360-student teacher 2000/2001 population from all 9 different preservice programs.
\end{abstract}

\section{Introduction}

The information and communication technologies structure a new way of thinking about education [1]. In fact, teachers can no longer assume the role of knowledge assimilators and deliverers and schools must become spaces for an ongoing negotiation in which both teachers and students search for and deliver information. The Nets (Inter- or Intra-) make possible both the distribution of all types of learning materials and the communication between the users and the educational system [2]. The Internet and its educational applications have thus become the focus of attention worldwide, with particular emphasis on their appropriation by educators.

Electronic collaboration can be an effective means of communication and of collaboration for novice teachers [3]. However, it isn't easy to change the way teachers exercise their profession because what they know and are familiar with is the basis for the way they go about their teaching activities. Moreover, teachers don't always accept those challenges which entail an unpredictable outcome. There have been concerns with the adequate planning of technology development in schools [4]. We too believe a positive influence can be exerted on teachers regarding technological innovation, we took it upon us to investigate those reasons which can motivate prospective teachers to use the Internet. In a previous report [5], we showed that, in general, our university's student teachers expressed favorable opinions about the Internet. However, they reported a very limited actual use of it in their academic activities, particularly as a means of communication and interaction. A few questions arose from our previous findings. These are the ones which we will be addressing in this report: how often did student teachers nse the Intemet during their teaching practice and what reasons motivated them to do so? What are their perceptions of Internet usage in their own schools and in their own disciplinary group?

\section{Sample and Data Collection}

We collected our data with a questionnaire for which there were 189 anonymous responses from our 2000/2001 academic year entire 360-student teacher population. The sample's ages range from 22 to 44 with mean 24.7, and both mode and median 23 , and the third quartile 25 . There were 159 females and 30 males distributed by a total of 9 preservice education programs (Table 1). There is 1 missing answer from a female student. During their 5-year preservice education programs all prospective teachers have the same general education courses, along with courses specific to each program. In their $4^{\text {th }}$ year all students have a didactics course specific to their area. Physics/Chemistry students also have an Introduction to Informatics course in their $1^{\text {st }}$ year; Mathematics Education students have Introduction to Programming in the $1^{\text {st }}$ year and Informatics in Teaching in the $4^{\text {th }}$ year.

For their teaching practice the student teachers were distributed in groups of three or four by two types of schools in which they had the opportunity to teach at either a basic level ( $7^{\text {hh }}$ to $9^{\text {th }}$ grades) or the secondary level $\left(10^{\text {th }}\right.$ to $\left.12^{\text {th }}\right)$ or both. Fifty-four of the respondents reported having had previous teaching experience, and 45 did private tutoring, while only 26 had taught in public schools and 3 in private schools. 


\begin{tabular}{lcccccc}
\hline \multirow{2}{*}{ Preservice Education Programs } & \multicolumn{2}{c}{ Females } & \multicolumn{2}{c}{ Males } & \multicolumn{2}{c}{ Total } \\
\cline { 2 - 7 } & $\mathrm{f}$ & $\%$ & $\mathrm{f}$ & $\%$ & & $\%$ \\
\hline Biology/Geology & 18 & 11.4 & 1 & 3.3 & 19 & 10.1 \\
English/German & 18 & 11.4 & 1 & 3.3 & 19 & 10.1 \\
History & 11 & 7.0 & 4 & 13.03 & 15 & 8.0 \\
Mathematics & 40 & 25.3 & 12 & 40.0 & 52 & 27.7 \\
Physics/Chemistry & 20 & 12.7 & 7 & 23.3 & 27 & 14.4 \\
Portuguese & 10 & 6.3 & 1 & 3.3 & 11 & 5.9 \\
Portuguese/English & 22 & 13.9 & 1 & 3.3 & 23 & 12.2 \\
Portuguese/French & 8 & 5.1 & 1 & 3.3 & 9 & 4.8 \\
Portugues/German & 11 & 7.0 & 2 & 6.7 & 13 & 6.9 \\
Total & 158 & 100 & 30 & 100 & 188 & 100 \\
\hline
\end{tabular}

Table 1: Distribution of student teachers by preservice programs and sex

\section{Student Teachers' perceptions of Internet usage and discussion in their schools and in their own disciplinary groups}

The debate about new roles for both students and teachers within the new Internet environments has become of undeniable importance. We believe that student teachers can have an important role in the innovation of teaching/learning approaches. Therefore

Graph 1: Student teachers' perceptions of Internet discussion by other teachers in their schools

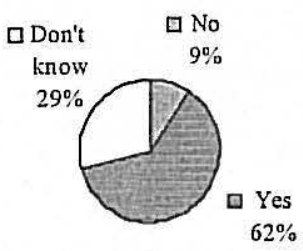

Graph 3: Student Teachers' perceptions of Internet discussion in their own disciplinary groups

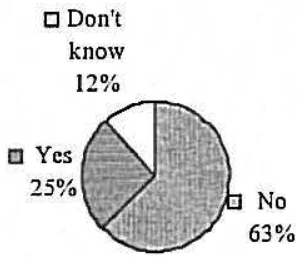

we questioned ourselves about their perceptions of what was going on in their schools and, in particular, in their own disciplinary group, as far as Internet usage and discussion are concerned. We stated the following: "In your school there are teachers use the Internet in their teaching"; "In your school there are teachers who talk about the Internet"; "In your disciplinary group some teachers use the Internet for teaching"; "Your group discusses the use of Internet for teaching".

Graph 2: Student teachers' perceptions of Internet usage by other teachers in their schools

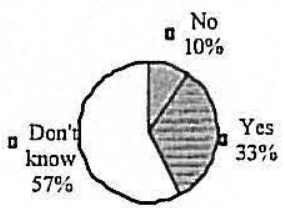

Graph 4: Student Teachers' perceptions of Internet usage in their own disciplinary groups

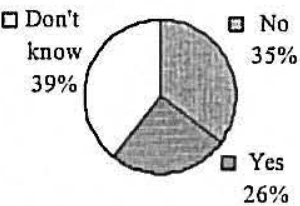


The majority of the student teachers (62\%) seem to have heard some talking about the Internet going on in the schools (Graph 1). However, as far as Internet usage in teaching by other teachers is concerned, the responses indicate that $57 \%$ of the student teachers did not have a clue about it (Graph 2).

The student teachers' perception of Internet discussion and usage by the teachers in their own disciplinary groups seems quite limited. It is most striking that, while $63 \%$ of them reported that there was no such debate, $12 \%$ did not know whether there was any discussion about the issue in their own disciplinary groups (Graph 3 ). Also quite a number $(39 \%)$ reported not knowing whether the teachers in their own groups used the Internet to teach (Graph 4).

\section{Student teachers' Internet usage: frequency, influence/motivation, and purpose}

Of 181 student teachers who reported having a computer at home, $51 \%$ said that they had Internet connection Among the very few students who reported not having a computer at home, there were 4 history majors, 1 Mathematics, 1 Physics/Chemistry, 1 Portuguese. As far as using the computer is concerned, students did it most frequently in their own homes, not so often at the university. Student teachers' Internet usage during their student teaching year ranged from never $(10 \%)$ and rarely $(24 \%)$ to once $(20 \%)$ or twice $(20 \%)$ a week and almost everyday (26\%). For the purpose of analysis, because there were few students in some education programs, the responses were grouped in "never or rarely" and "once or twice a week or almost everyday". A chi-square test found statistically significant $(p<0.01)$ differences between the education programs. Graph 5 depicts these differences: the percentage of student teachers who reported having never or rarely used the Internet during their student teaching year was the highest for the Portuguese preservice program ( $80 \%$ ), followed by Portuguese/German (54\%), English/German (47\%), and Portuguese/French (44\%). On the other hand, both Biology/Geology (79\%) and Mathematics $(79 \%)$ were the programs in which more students reported having used the Internet at least once a week, followed closely by History $(73 \%)$ and Physics/Chemistry $(70 \%)$.

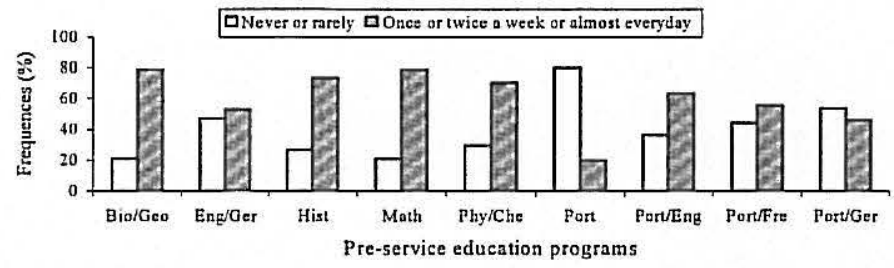

Graph 5: Internet usage by the different majors' student teachers

There were no significant differences between males and females as to frequency of Internet usage. Nevertheless, more males than females reported having used the Internet at least once a week.

Student teachers were asked how often supervisors' suggestion/requirement or peers' suggestion had influenced their Internet usage. Supervisors do not seem to have been very influential, neither suggesting or requiring the student teachers to use the Internet. On the other hand, peers are the ones more frequently identified by the student teachers as having had some influence (Table 2).

\begin{tabular}{|c|c|c|c|c|c|}
\hline \multirow{2}{*}{ Source of influence } & \multicolumn{2}{|c|}{ University Supervisor } & \multicolumn{2}{|c|}{ School supervisor } & \multirow{2}{*}{$\begin{array}{c}\text { Peers' } \\
\text { Suggested }(\%)\end{array}$} \\
\hline & Suggested (\%) & Required $(\%)$ & Suggested $(\%)$ & Required (\%) & \\
\hline Never & 58.2 & 84.1 & 48.1 & 84.1 & 28.6 \\
\hline Rarely & 27.0 & 8.5 & 33.9 & 6.9 & 42.9 \\
\hline Many times & 7.4 & 1.6 & 9.5 & 2.6 & 5.8 \\
\hline Frequently & 1.6 & 0.5 & 3.7 & 1.1 & 19.0 \\
\hline Missing & 5.8 & 5.3 & 4.8 & 5.3 & 3.7 \\
\hline
\end{tabular}

Table 2: Sources of influence on student teachers' Internet usage

We believed that both foreign language skills and the kind of specific materials available on the WWW might be a factor in the frequency of either peers' or supervisors' suggestion/requirement for Internet usage. Therefore, the education programs were grouped in the following way: Biology/Geology, Mathematics, Physics/Chemistry, Portuguese, and History standing by themselves; all programs involving foreign language preparation (English/German, Portuguese/English, 
Portuguese/French, Portuguese/German) grouped together. Chi-square tests were performed for each of the sources of influence, but differences were found only for the university supervisor's suggestion $(\mathrm{p}<0.05)$ and for peers' suggestion $(\mathrm{p}<0.01)$. Table 3 shows the distributions of student teachers' responses for each of the two. It can be seen that in each of the education programs peers' influence was more frequent than that of the university supervisor. Peers' influence is greater for Physics/Chemistry and Biology/Geology majors. Biology/Geology university supervisors are the ones most influential, followed by History's, Physics/Chemistry's, and Mathematics'.

\begin{tabular}{lcccc}
\hline \multirow{2}{*}{ Grouped programs } & \multicolumn{2}{c}{ Peers' suggestion } & \multicolumn{2}{c}{ University supervisor' suggestion } \\
\cline { 2 - 5 } & $\begin{array}{c}\text { Never or } \\
\text { rarely }(\%)\end{array}$ & $\begin{array}{c}\text { Many times or } \\
\text { frequently }(\%)\end{array}$ & $\begin{array}{c}\text { Never or } \\
\text { rarely (\%) }\end{array}$ & $\begin{array}{c}\text { Many times or } \\
\text { frequently (\%) }\end{array}$ \\
\hline Biology/Geology & 52.6 & 47.4 & 73.7 & 26.3 \\
Physics/Chemistry & 55.6 & 44.4 & 88.0 & 12.0 \\
Mathematics & 74.0 & 26.0 & 87.5 & 12.5 \\
History & 76.9 & 23.1 & 84.6 & 15.4 \\
Foreign languages & 84.4 & 15.6 & 98.4 & 1.6 \\
Portuguese & 100.0 & 0.0 & 100.0 & 0.0 \\
\hline
\end{tabular}

Table 4 shows the frequency distributions of student teachers' purpose of Internet usage. It can be seen that the majority of the student teachers reported having never or rarely used the Internet for any of the listed purposes. To communicate with colleagues, to chat on line, and to show web sites to students were the least rated goals. To find ideas for classes, using email, and finding software for classes were the most indicated goals pursued many times or frequently.

Mann Whitney $U$ tests show significant differences between males and females for email usage $(p<0.05)$, finding ideas for classes $(\mathrm{p}<0.05)$, and finding software for classes $(\mathrm{p}<0.01)$, with mean ranks higher for males on the three items. That is, males reported a higher rate of usage. Some differences, although not significant at the 0.05 level, were found for going to see web pages with the students ( $p=0.058$ ), again with a higher rate of usage for the males. No differences were found between males and females in any of the other items.

\begin{tabular}{lccccc}
\hline Used the Internet & Never \% & Rarely \% & Many times \% & Frequently \% & Missing \% \\
\hline For fun & 46.0 & 36.5 & 7.9 & 4.2 & 5.3 \\
For email & 34.4 & 30.7 & 20.1 & 10.6 & 4.2 \\
For on line chatting & 77.2 & 14.3 & 2.1 & 2.1 & 4.2 \\
For web pages construction & 82.5 & 5.8 & 4.2 & 1.6 & 5.8 \\
To find ideas for my classes & 13.8 & 38.1 & 31.7 & 13.2 & 3.2 \\
To find software for my classes & 29.1 & 36.5 & 21.2 & 9.0 & 4.2 \\
To communicate with colleagues & 78.8 & 12.7 & 2.12 & 2.1 & 4.2 \\
To show Internet things to my students & 38.1 & 41.8 & 11.1 & 5.8 & 3.2 \\
To suggest web pages to my students & 37.6 & 38.6 & 13.2 & 7.4 & 3.2 \\
To visit web sites with my students & 63.5 & 27.0 & 3.2 & 2.1 & 4.2 \\
\hline
\end{tabular}

Table 4: Frequency distributions of the purpose of Internet usage by student teachers

Using Kruskal Wallis tests, statistically significant differences between the different majors were found only for suggesting web pages to the students $(\mathrm{p}<0.05$ ), with higher mean ranks for Biology and History majors. Some differences, although not statistically significant at the 0.05 level, were found for finding ideas for class $(p=0.068)$, with higher mean ranks for Biology, Portuguese/English, Physics/Chemistry, and Portuguese/French. For finding software for class, Mathematics, and Physics/Chemistry had the highest mean ranks.

\section{Conclusions}

Most of the 189 student teachers who answered our questionnaire did not use the Internet very often during their student teaching, not even for fun. Actually, $10 \%$ of them reported never having used it at all. This is most revealing of a situation which does not seem to fit into technological advances of the XXI century. But how revealing is the fact that most student teachers indicate that their limited Internet usage was not influenced by requirement or even suggestion from their supervisors? The question we asked was 'how often supervisors' suggestion/requirement had influenced their actual 
Internet usage". We did not ask "how often advisors required/suggested that they used the Internet in their academic activities". Therefore, there is not much that we can infer from it. We should only mention that Biology/Geology university supervisors are the ones most indicated by the student teachers as having influenced their Internet usage, followed by History's, Physics/Chemistry's, and Mathematics'. Peers' influence was greater for Physics/Chemistry and Biology/Geology majors.

There was more frequent usage of the Internet by some majors' student teachers which we think has to do with the kind of materials available on the WWW, namely images and software. Foreign language skills may be a positive factor of the frequency of Internet usage. As we had expected, students majoring in Portuguese were the ones who reported having used the Internet less. To find ideas and software for classes and using email were the most indicated purposes. To communicate with colleagues, to chat online, and to show web sites to students were the least rated.

During their teaching practice the student teachers assume a double status: although they are still university students, they are also teachers in the sense that they assume the responsibility, albeit supervised, of teaching two classes on their own. Therefore, they are part of the school's staff and are expected to fully integrate its academic activities. This fact makes our findings most surprising: the student teachers, regardless of their majors, seem to have a very limited perception of what goes on in their schools and in their own disciplinary group with respect to Internet discussion and usage. And new questions arise: Why is it so? Is it an integration problem from the part of the student teachers? Or is there silence about these matters? If so, why? What do teachers think and know about the Internet? How can communication and collaboration be implemented in the schools? Will electronic communication be a good means to strengthen teachers' and student teachers' collaboration?

\section{References}

[1] Pretto, N., \& Serpa, L. (2001). A educação e a sociedade de informaçāo. In P. Dias, \& C. de Freitas. (Orgs.) Challenges 2001: Actas da II Conferência Internacional de Tecnologias de Informação e Comunicaçāo na Educaçāo (pp. 21 - 41). Braga: Centro de Competência Nónio da Universidade do Minho.

[3] Davis, B., \& Resta, V. K. (2002). Online Collaboration: Supporting Novice Teachers as Researchers. Journal of Technology and Teacher Education 10(1): 101-117.

[2] Trindade, A. (2001). Educação e formaçāo à distância. In P. Dins, \& C. de Freitas. (Orgs.), Challenges 2001: Actas da II Conferência Internacional de Tecnologias de Informação e Comunicação na Educação (pp.55-63). Braga: Centro de Competência Nónio da Universidade do Minho.

[4] Ainisu, iv. E. \& Vasu, E. S. (2000). Vítusuting Knowledge of Technology Usage and Stages of Concern About Computing: A Study of Middle School Teachers. Journal of Technology and Teacher Education 18(4): 279-302.

[5] Almeida, C., Martinho, H., Viseu, F., Morais, C., \& Miranda, L. (2002). Portuguese student teachers' experiences, perspectives and expectations regarding the use of the Intemet: the impact of a preservice program. In D. A. Willis, J. Price, \& N. Davis (Eds.), Information Technology \& Teacher Education Annual: Proceedings of SITE 2002 (pp.1232-1235). Norfolk, VA: Association for the Advancement of Computing in Education. 